\section{Medical Faculty Students' Attitudes, Behaviors and Beliefs About Covid-19 Pandemic}

\author{
Tıp Fakültesi Öğrencilerinin Kovid-19 Pandemisine \\ ilişkin Tutum, Davranış ve inançları
}

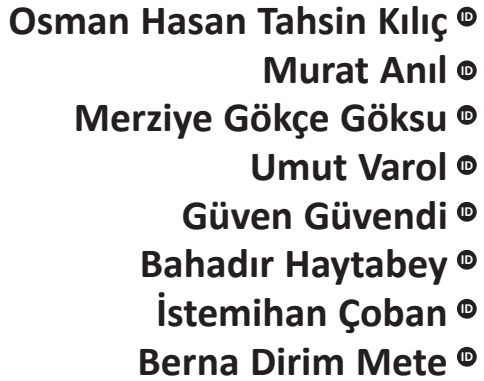

Received: 03.01 .2021

Accepted: 14.01 .2021

Objective: The aim of this study is to evaluate the attitudes, behaviors, and beliefs of medical faculty students about the covid-19 pandemic.

Methods: Between 29/03/2020 and 04/13/2020 a total of 1,332 students had been questioned in three Turkish speaking countries (Turkey, Azerbaijan, Turkish Republic of Northern Cyprus).

Results: The average age of the students were $20.1 \pm 1.6$. Among all 895 (67.7\%) of them were female and 427 (32.3\%) were male. 1020 (77.2\%) of the studens were in Turkey, 195 (14.8\%) were in Azerbaijan and 107 (8.1\%) were in the TRNC. 104 of the students (7.9\%) had a chronic disease. It was found that number of alcohol and cigarette users decreased significantly during the pandemic. $(p<0.001, p<0.001)$. Anxiety levels of those who quit or reduced smoking were found to be higher than those who increased or did not change their amount of smoking ( $p=0.034)$. It was found that the most benefited sources were "their faculty lecturers" ( $n=453,34.3 \%)$, "Worldometer ${ }^{\circledR}$ website" ( $\left.n=449,34 \%\right)$ and "Youtube videos" ( $n=396$, $30 \%)$.

Conclusion: Longitudinal studies are needed on the effects of pandemic on alcohol and tobacco use. It is important to educate future physicians in social media literacy, interpretation and responsibilities for social media posts. In this way, perhaps we can contribute to minimize the public's erroneous beliefs and maladaptive behaviors regarding the pandemic and reduce stigmatizing attitudes towards physicians, elders and Asians.

Keywords: COVID-19, pandemic, medical student, MSIC, social media

öz

Amaç: Bu çalışmanın amacı, tıp fakültesi ögrrencilerinin covid-19 pandemisi hakkında tutum, davranış ve inanışlarını değerlendirmektir.

Yöntem: 29.03.2020 ve 13.04.2020 tarihleri arasında Türkçe konuşulan üç ülkede (Türkiye, Azerbaycan, Kuzey Kıbrıs Türk Cumhuriyeti) toplam 1.332 Tıp Fakültesi öğrencisine çevrimiçi anket uygulandı.

Bulgular: Çalışmaya katılan öğrencilerin yaş ortalaması $20.1 \pm 1.6$ idi. 895'i (\% 67,7) kadın, 427'si $(\% 32,3)$ erkekti. Öğrencilerin 1020'si (\% 77,2) Türkiye' de, 195'i (\% 14,8) Azerbaycan'da ve 107'si $(\%$ 8,1) KKTC'de eğitim görmekte idi. Öğrencilerin 104'ü $(\%$ 7,9) sürekli ilaç kullanımı gerektiren kronik bir hastalığa sahipti. Pandemi döneminde alkol tüketen ve sigara kullanan öğrenci sayısının azaldığı saptandı(p<0.001, $p<0.001)$. Sigarayı kullanmayı bırakan veya azaltanların anksiyete düzeyleri kullanmaya devam eden veya arttıranlara göre yüksek saptandı $(p=0.034)$. Öğrencilerin pandemi hakkındaki bilgilerini en sık olarak kendi fakültelerindeki öğretim üyelerinden ( $n=453,34.3 \%)$, Worldometer internet sitesinden $(n=449,34 \%)$ ve Youtube videolarından aldığı saptandı ( $n=396,30 \%)$.

Sonuç: Pandeminin alkol ve tütün kullanımına etkilerini inceleyecek uzun süreli çalışmalara ihtiyaç vardır. Geleceğin hekimlerini sosyal medya okuryazarlığı, yorumlaması ve paylaşım sorumlulukları konusunda eğitmek önemlidir. Bu şekilde, belki de toplumun pandemiye ilişkin hatalı inançlarının ve uyumsuz davranışlarının, hekimlere, yaşlılara ve Asyalılara yönelik damgalayıcı tutumlarının azaltılmasına katkıda bulunabiliriz.

Anahtar kelimeler: COVID-19, pandemi, tıp fakültesi öğrencisi, MSIC, sosyal medya

\author{
Published Online: 30.04 .2021
}

Cite as: Kılıç OHT, Anıl M, Göksu MG, Varol U, Güvendi $G$, Haytabey B et al. Medical faculty students' attitudes, behaviors and beliefs about Covid-19 pandemic. İzmir Dr. Behçet Uz Çocuk Hast. Dergisi. 2021;11(1):57-65.

İstemihan Çoban

İzmir Demokrasi Üniversitesi Tıp

Fakültesi, Anatomi Anabilim Dalı

İzmir, Türkiye

- istemihancoban@gmail.com ORCID: 0000-0001-7104-2118

O. H. T. Kılıç 0000-0001-7070-6808 izmir Demokrasi Üniversitesi Tıp Fakültesi Ruh Sağlığı ve Hastalıkları Anabilim Dalı, izmir, Türkiye

M. Anıl 0000-0002-2596-4944 İmir Demokrasi Üniversitesi Tıp Fakültesi Çocuk Sağlığı ve Hastalıkları Anabilim Dalı, izmir, Türkiye

M. G. Göksu 0000-0002-2508-0647 İzmir Demokrasi Üniversitesi İmir, Türkiye

U. Varol 0000-0002-4669-2052 İmir Demokrasi Üniversitesi Tıp Fakültesi iç Hastalıkları ve Onkoloji Anabilim Dalı Izmir, Türkiye

G. Güvendi 0000-0002-1858-162X Izmir Demokrasi Üniversitesi Tıp Fakültesi Fizyoloji Anabilim Dalı, İmir, Türkiye

B. Haytabey 0000-0002-6123-8982 Adnan Menderes Üniversitesi, Aydın, Türkiye

B. Dirim Mete 0000-0002-2380-4197 İmir Demokrasi Üniversitesi Tıp Fakültesi Radyoloji Anabilim Dalı, İzmir, Türkiye 


\section{INTRODUCTION}

A new type of coronavirus-related pneumonia cases were reported for the first time in December 2019 in Wuhan Province of People's Republic of China. The epidemic spread rapidly all over the world. The World Health Organization (WHO) defined the newly identified virus as SARS-CoV-2 (severe acute respiratory syndrome coronavirus 2 ) and its disease as COVID-19 (Coronavirus Disease 2019) in February 2020. WHO, then, declared that this epidemic is a pandemic on March 11th, 2020. According to WHO, COVID-19 has been detected in 3,090,045 people in 213 countries and 217,769 people were lost by April 30th, $2020^{(1)}$.

The COVID-19 outbreak continues to pose a threat to people's lives and health in almost every country in the world. The rapid progress of this pandemic caused crises in health systems in Italy and Iran. It has led to early graduations of medical students in the USA, Italy and the UK to ensure that senior medical school students are at the forefront to combat the pandemic ${ }^{(2)}$. Waiting for students to take an active role in pandemic by interrupting their medical education or continuing only online education constitutes a contradiction (3). In the past, there were examples where medical school students have been actively involved in outbreaks. Medical students took their place in the fight against the epidemics of 1918 Spanish influenza in the USA and 1952 polio epidemic in Denmark (2).

The future health professionals are not directly involved in our country in the fight against the pandemic. However, we think that their attitudes, perceptions, the sources of information they refer to and their beliefs about the pandemic may affect the society.

Although there are many studies investigating the level of anxiety and knowledge of healthcare workers and the general community in pandemics, only a few publications have investigated the level of anxiety of medical students or their attitudes, behaviours and beliefs about the current pandemic ${ }^{(4-6)}$.

We think that it is important to comprehend medical students' attitudes and beliefs in order to prepare for the bad scenarios and plan the future appropriately in this pandemic, where we still cannot predict its end and consequences. For this purpose, we planned a survey study evaluating the anxiety levels of the medical students, their protective measures for the epidemic, their sources of information and their general beliefs in this pandemic.

\section{MATERIALS and METHODS}

A total of 1,332 students had been questioned via an online survey in three Turkish speaking countries (Turkey, Republic of Azerbaijan, Turkish Republic of Northern Cyprus (TRNC)). The survey was open between 03.29. 2020 and 04.13. 2020. At the time of the study, 23 days had passed since the first case of COVID-19 was seen in Turkey and 95 days since the first case was seen in the World.

A questionnaire was used as a data collection tool which includes 32 questions about sociodemographic and educational data, alcohol consumption and tobacco use, anxiety levels, used sources of information about pandemic, activities during isolation and quarantine period, personal protection measures, their care when using stigmatic expressions associated with the pandemic, and beliefs about vaccine and conspiracy theories.

The survey was created through the online survey portal SurveyMonkey ${ }^{\circledR}$ (www.tr.surveymonkey.com). The link of the survey was sent to the WhatsApp ${ }^{\circledR}$ accounts of TurkMSIC, Azerbaijan Physicians and Medical Students Association (AzerMDS) and members of the Medical Students Association of Northern Cyprus (MSANC).

TurkMSIC is an independent, non-profit, nonpolitical organization formed in 1952 by medical students in Turkey. There are local representatives of the organization in 82 medical faculties across the country with a gross network encompassing more than 30,000 medical students. It represents Turkey at an international level within the International Medical Students' Associations Federation (IFMS). 
The ethics committee approval for the study was obtained from the Non-Interventional Clinical Research Ethics Committee of Izmir Democracy University (dated March 20th 2020 and numbered 2020 / 08-4). Approval of the Ministry of Health was obtained on May 5th 2020.

\section{Statistical Analysis}

Survey results were analyzed with IBM SPSS 20.0 Statistics (IBM Corporation, New York, USA) package program. Categorical data were indicated by numbers (n) and percentages (\%). The numerical data that met the parametric assumptions are shown with arithmetic mean \pm standard deviation (mean \pm SD) and minimum-maximum (min-max) values; those that did not meet the parametric assumption were expressed with median and interquartile range (IQR). Chi-square test was used to compare categorical data. Post-hoc Bonferroni test was used to compare more than two groups. Mann-Whitney $U$ test was used to compare two independent variables that did not meet the parametric assumptions, and Kruskall Wallis test was used to compare more than two nonparametric variables. The relationship between the two groups was examined with Spearman correlation analysis. $p<0.05$ value was considered statistically significant.

\section{RESULTS}

A total of 1,322 medical school students took the survey. The mean age of the students was $20.1 \pm 1.6$ years. The study population consisted of 895 (67.7\%) female and 427 (32.3\%) male students. The students were living in Turkey (1020:77.2\%), Republic of Azerbaijan ( $n=195: 14.8 \%)$ and TRNC ( $n=107: 8.1 \%)$. The students were in their first $(n=595: 45 \%)$, second $(n=309: 23.3 \%)$, third $(n=, 219: 16.5 \%)$, fourth $(n=83$ $: 6.2 \%)$, fifth ( $n=93(7 \%)$, and sixth ( $n=23: 1.7 \%)$ year of their medical education A total of 104 (7.9\%) students had a chronic disease that required continuous use of medication.

Before WHO announced COVID-19 as a pandemic, $284(21.5 \%)$ participants stated that they were smokers. After the announcement, 108 (8.2\%) participants stated that they quit smoking and 127 (9.6\%) participants stated that they reduced the pack-years of cigarettes smoked. The number of smokers ( $n=284,21.5 \%$ ) were significantly reduced $(n=17613.3 \%)$ after the announcement of pandemic $(p<0.001)$.

A total of 498 (37.7\%) students stated that they consumed alcohol regularly before pandemic. After the announcement of the outbreak 113 (8.5\%) students stated that they quit drinking alcoholic beverages and 202 (15.3\%) students indicated that they reduced their weekly alcohol consumption. The number of alcohol users ( $n=385,29.1 \%)$ decreased significantly after the announcement of the pandemic $(n=498,29.1 \%)(p<0.001)$.

Students were asked to score, and rate their "anxiety levels about pandemic" between 1 to 10 points ( 1 point is "I am not anxious" and 10 points is "The most severe anxiety I have ever experienced"). The median score of anxiety levels about pandemic was $6(I Q R=5-7)$ points (Figure 3). Anxiety scores of females were significantly higher $(p<0.001)$. There was no significant correlation between students' age and their anxiety scores $(p=0.598 ; r=0.015)$. The median anxiety scores of participants from Turkey, Azerbaijan and TRNC were $6(\mathrm{IQR}=5-7), 6(\mathrm{IQR}=5-7)$ and $6(\mathrm{IQR}=4-7)$ points, respectively without any significant difference among them $(p=0.680)$.

Anxiety scores of smokers were found to be significantly lower $(p=0.013)$. The median anxiety scores of students whose daily amount of cigaterres smoked increased, decreased, did not change, and of quitters were 4 (IQR=2-6), 6 (IQR=4-7), 5 (IQR=3-7) and $6(I Q R=4-7)$ points respectively. When these four goups were compared, the anxiety levels of those who quitted or reduced smoking were found to be higher than those who increased or did not change their amount of smoking ( $p=0.034)$.

Students' behavior towards personal protection was also investigated during the pandemic. Most ( $n=1197: 90.5 \%$ ) participants stated that they applied standard hand washing methods every time they washed their hands and 1059 (80.1\%) participants purchased or obtained hand disinfectants. Besides, 868 (65.7\%) participants stated that they always 
wore medical masks when they were outside and $1132(85.7 \%$ ) of them indicated that they did not get out of home except for obligatory situations.

Those who wore medical gloves $(p<0.001)$, medical masks $(p<0.001)$, and carried with them bottles of hand disinfectants $(p<0.001)$, and/or eau de cologne which contains a mixture of citrus oils including oils of lemon, orange, tangerine, clementine, bergamot, lime, grapefruit and orange in a base of dilute ethanol $(70-90 \%)],(p<0.001)$, and complied with hand washing methods $(p=0.001)$ reported higher anxiety levels (Table 1).

Information sources of the participants were their faculty lecturers" ( $n=453,34.3 \%)$, "Worldometer ${ }^{\circledR}$ website" ( $\left.n=449,34 \%\right)$ and "Youtube videos" ( $n=396,30 \%$ ) (Figure 1).

When three countries were compared in terms of age,gender alcohol/tobacco use, anxiety scores, and medical mask use; any significant difference was not found between age and anxiety scores of the students $(p>0.05$ and $p>0.05)$. The number of female participants were slightly higher in Azerbaijan than other two countries $(p=0.046)$. Highest rates of smoking and alcohol use were found among TRNC students both before and during pandemic. In Turkey, Azerbaijan and TRNC, respective rates of smoking before $(22.5 \%, 9.7 \%, 33.6 \%, p=0.001)$ and during pandemic $(14.1 \%, 5.6 \%$, and $19.6 \%, p=0.001)$ were as indicated. In Turkey, Azerbaijan and TRNC respective rates of alcohol consumption before (40.9\%, 15.4\%, and $47.7 \%, p=0.001)$ and during $(31.8 \%, 10.3 \%$, and $38.3 \%, p=0.001)$ pandemic were as indicated. Highest rates of mask use were observed in Azerbaijan $(p=0.001)$. Comparison of three countries in terms of demographic variables, alcohol/ tobacco use, anxiety scores, and medical mask use is shown in Table 2.

When in-house activities practiced by medical school students during isolation or quarantine period were evaluated, it was found that the biggest share was taken by household activities as watching movies or TV series ( $n=1235,93.4 \%)$, spending time with social media (Facebook, Instagram, Twitter etc.) ( $n=1206,91.2 \%)$ and chatting with their friends via

Table 1. Factors affecting medical students' anxiety scores.

\begin{tabular}{|c|c|c|c|c|}
\hline Variable & 25 & Median & 75 & $\mathbf{p}$ \\
\hline \multicolumn{5}{|l|}{ Sex } \\
\hline Male $(n=427,32.3 \%)$ & 4 & 5 & 7 & $<0,001^{*}$ \\
\hline Female $(n=895,67.7 \%)$ & 5 & 6 & 7 & \\
\hline \multicolumn{5}{|l|}{ Smoking rates during pandemic } \\
\hline Increased $(n=6,0.5 \%)$ & 2 & 4 & 6 & $0,0341 * *$ \\
\hline Decreased $(n=127,9.6 \%)$ & 4 & 6 & 7 & \\
\hline Didn't change $(n=43,3.3 \%)$ & 3 & 5 & 7 & \\
\hline Quittted smoking ( $n=108,8.2 \%)$ & 4 & 6 & 7 & \\
\hline I don't smoke $(n=1038,78.5 \%)$ & 5 & 6 & 7 & \\
\hline \multicolumn{5}{|c|}{ I always practice the standard hand washing method } \\
\hline Yes $(n=1197,90.5 \%)$ & 5 & 6 & 7 & $0,001^{*}$ \\
\hline No $(n=120,9.1 \%)$ & 4 & 5 & 7 & \\
\hline \multicolumn{5}{|l|}{ I carry hand sanitizer with me } \\
\hline Yes $(n=620,46.9 \%)$ & 5 & 6 & 8 & $<0,001^{*}$ \\
\hline No $(n=681,51.5 \%)$ & 4 & 6 & 7 & \\
\hline \multicolumn{5}{|l|}{ I carry hand cologne with me } \\
\hline Yes $(n=731,55.3 \%)$ & 5 & 6 & 8 & $<0,001^{*}$ \\
\hline No $(n=579,43.8 \%)$ & 4 & 6 & 7 & \\
\hline \multicolumn{5}{|l|}{ I wear a medical mask outside } \\
\hline Yes $(n=675,51.1 \%)$ & 5 & 6 & 8 & $<0,001^{*}$ \\
\hline No $(n=627,47.4 \%)$ & 4 & 6 & 7 & \\
\hline \multicolumn{5}{|l|}{ I wear medical gloves outside } \\
\hline Yes $(n=526,39.8 \%)$ & 5 & 7 & 8 & $<0,001^{*}$ \\
\hline No $(n=778,58.9 \%)$ & 4 & 6 & 7 & \\
\hline
\end{tabular}

*: Mann Whitney U Test; **: Kruskal Wallis Test; 1: the median values of the "increased" and "didn't change" groups were statistically lower than the other two groups. 


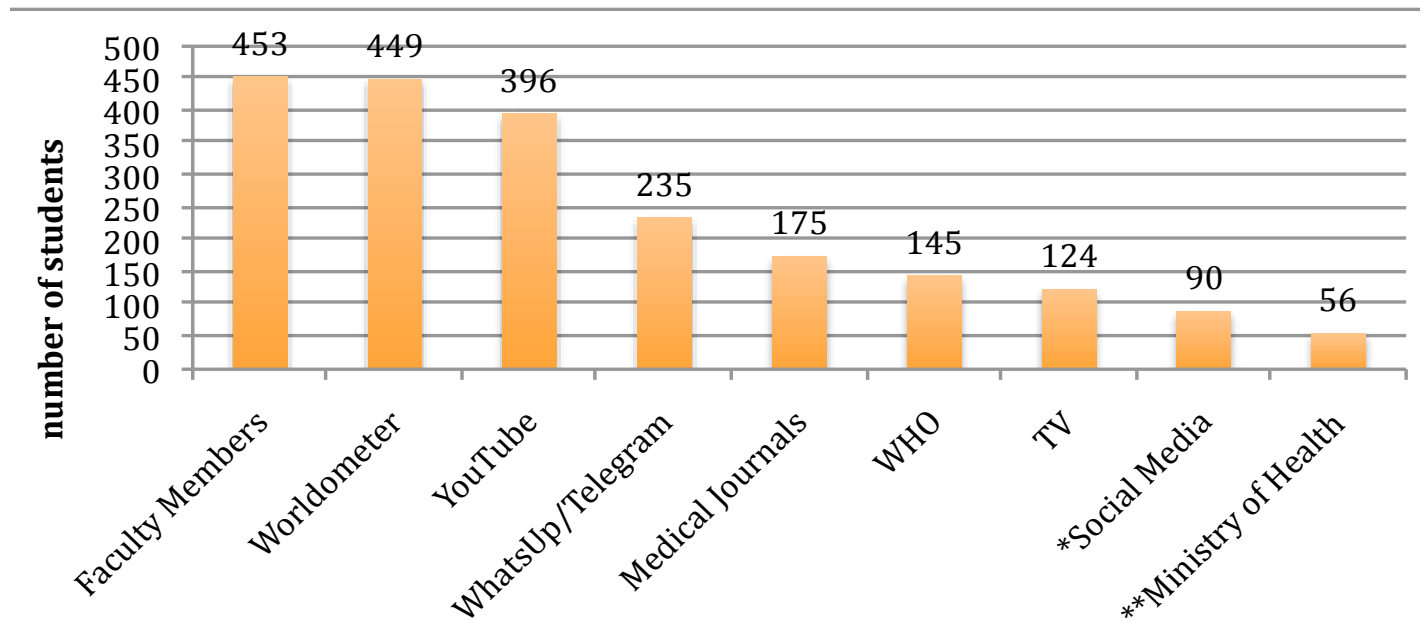

Figure 1. Sources used for getting information about pandemic.

*Facebook/Instagram/Twitter;

**Official websites of their country's health ministries

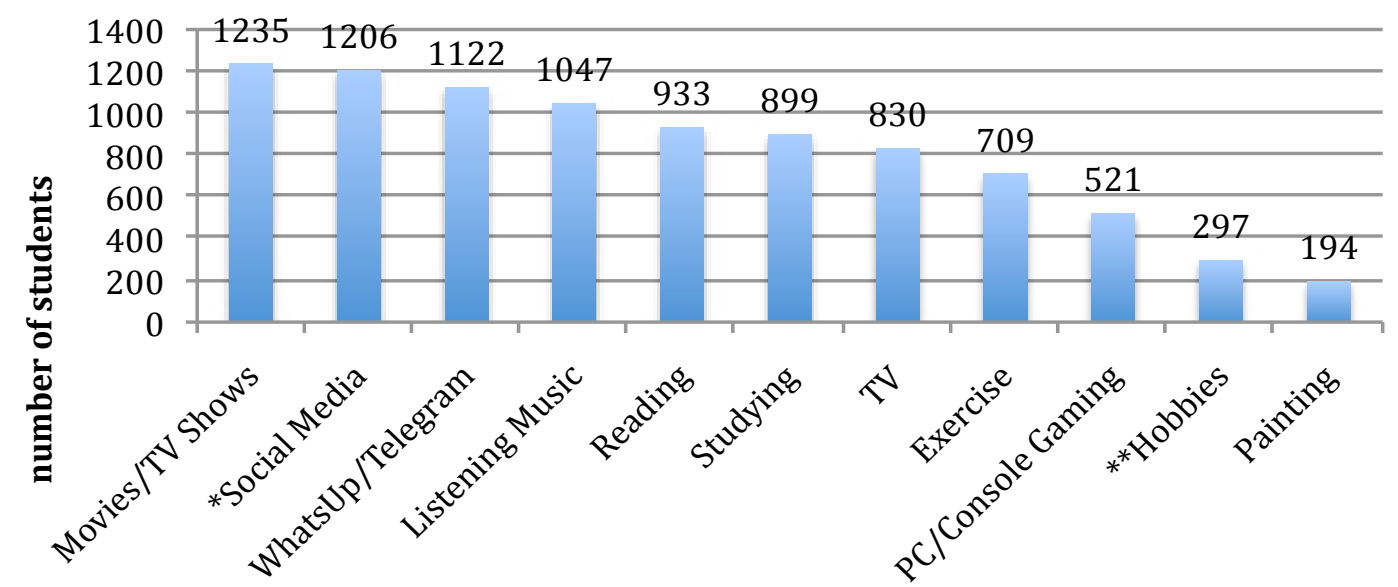

Figure 2. In-house activities of medical students during isolation/quarantine periods.

*Facebook/Instagram/Twitter;

**Handicrafts, culinary arts, etc., except music and painting

WhatsApp or Telegram ( $n=1122,84.9 \%)$ (Figure 2).

When students were asked about their beliefs on a probable vaccine, $814(81.6 \%)$ of them stated that they believed a vaccine would be developed within a year." While 774 (58.5\%) of them stated that "the probable COVID-19 vaccine would reduce antivaccine movement in the world" Three hundred and forty $(25.7 \%)$ participants indicated that the perception about vaccine would not change and 184 (13.9\%) of them stated that anti-vaccine movement would grow.

When asked how this pandemic would affect the attitudes of the society towards healthcare professionals, most of the students ( $n=96673.1 \%$ ) stated that the society would have a more positive perspective. While others ( $n=329: 24.9 \%$ ) indicated that it would not change their viewpoints, and a few of them ( $n=23: 1.7 \%$ ) asserted that the people would more frequently develop negative attitude towards health professionals

When students asked about their wievs about conspiracy theories about SARS CoV-2 virus; 163 $(12.3 \%)$ students stated that SARS CoV-2 was definitely a biological weapon, while 333 (25.2\%) of them indicated that SARS CoV-2 might be a biological weapon. The rest of the students ( $n=529: 40 \%)$ 
Table 2. Comparison of three countries in terms of demographic variables, alcohol/tobacco use, anxiety scores, and medical mask use.

\begin{tabular}{|c|c|c|c|c|}
\hline & $\begin{array}{c}\text { Turkey } \\
(\mathrm{n}=1020,77.2 \%)\end{array}$ & $\begin{array}{c}\text { Azerbaijan } \\
(n=195,14.8 \%)\end{array}$ & $\begin{array}{c}\text { TRNC* } \\
(n=107,8.1 \%)\end{array}$ & p-value \\
\hline Age (mean \pm SD) $(20.1 \pm 1.6$ years $)$ & $19.9 \pm 1.4$ & $21.0 \pm 1.7$ & $20.9 \pm 2.7$ & $p>0.05$ \\
\hline \multicolumn{5}{|l|}{ Gender } \\
\hline Female $(n=895,67.1 \%)$ & $632(66.9 \%)$ & $146(74.9 \%)$ & $67(62.6 \%)$ & \\
\hline Male $(n=437,32.8 \%)$ & $338(33.1 \%)$ & $49(25.1 \%)$ & 40 (37.4\%) & ${ }^{1} p=0.046$ \\
\hline Anxiety scores $(6, * * \mid Q R=5-7)$ & $6(\mathrm{IQR}=5-7)$ & $6(\mathrm{IQR}=5-7)$ & $6(\mathrm{IQR}=4-7)$ & $p>0.05$ \\
\hline Having a chronic disease $(n=104,7.9 \%)$ & $67(6.6 \%)$ & $18(9.2 \%)$ & $19(17.8 \%)$ & ${ }^{2} p=0.001$ \\
\hline Tobacco use before pandemic $(n=284,21.5 \%)$ & $229(22.5 \%)$ & $19(9.7 \%)$ & $36(33.6 \%)$ & ${ }^{3} p=0.001$ \\
\hline Tobacco use during pandemic $(n=176,13.3 \%)$ & $144(14.1 \%)$ & $11(5.6 \%)$ & $21(19.6 \%)$ & ${ }^{4} p=0.001$ \\
\hline Alcohol use before pandemic ( $n=498,37.3 \%)$ & 417 (40.9\%) & $30(15.4 \%)$ & $51(47.7 \%)$ & ${ }^{5} p=0.001$ \\
\hline Alcohol use during pandemic $(n=386,28.9 \%)$ & $324(31.8 \%)$ & $20(10.3 \%)$ & $42(38.3 \%)$ & ${ }^{6} p=0.001$ \\
\hline Mask use $(n=868,65.7 \%)$ & $628(61.6 \%)$ & $161(82.6 \%)$ & $79(73.8 \%)$ & ${ }^{7} p=0.001$ \\
\hline
\end{tabular}

${ }^{1}$ The significance was between Azerbaijan and the other two countries.

${ }^{2}$ The significance was between TRNC and the other two countries.

${ }^{3}$ The significance was between all three countries.

${ }^{4}$ The significance was between Azerbaijan and the other two countries.

${ }^{5}$ The significance was between Azerbaijan and the other two countries.

${ }^{6}$ The significance was between Azerbaijan and the other two countries.

${ }^{7}$ The significance was between all three countries.

asserted that SARS CoV-2 was not a biological weapon" and 290 (21.9\%) participants answered the question as "I have no idea"

The students were asked the question: "How much do you take care to avoid using stigmatizing expressions such as "Chinese virus" or "old people virus" in daily use?", and the responses were rated on a scale of 10 points (0: I do not care at all; 10: I pay attention to every statement). The average of the scores they obtained was $0(\mathrm{IQR}=0-5)$.

\section{DISCUSSION}

In this study, it was determined that number of alcohol and cigarette users decreased significantly during the pandemic. Anxiety levels were higher in those who quit or reduced smoking and those who comply with personal protection measures. Most of them get their information about the pandemic from their faculty lecturers or from Worldometer website or Youtube videos. One of three students believed that SARS CoV-2 is a biological weapon and a vaccine will be found in a year.

In a study conducted in Chinese medical school students, it was reported that one in four of them had anxiety symptoms and some sociodemographic factors such as living in the city, stable income in their families, and living with parents were protective against anxiety ${ }^{(5)}$. In our study, we did not find any significant relationship between socio-demografical factors (age, gender, country of residence, having a chronic disease) and anxiety levels, except gender. Anxiety levels in female students were higher. Concordant with our findings, exhaustion and anxiety levels were found to be higher in women healthcare workers and it has been reported that younger and female healthcare workers are more adversely affected during the current pandemic ${ }^{(7-9)}$.

In previous outbreaks, it has been reported that those with low levels of anxiety complied less with social distancing practices and hygiene measures ${ }^{(11)}$. Parallel to these data we found higher anxiety levels in those who applied protective measures (wearing a medical mask, providing hand disinfectant or eau de cologne and following hand washing methods). Our results show that people with very low anxiety levels may have maladaptive behaviors regarding compliance with preventive and hygiene measures. Feeling anxious to a real external threat like a pandemic is a natural and healthy response but people with very low anxiety levels may have maladaptive behaviors regarding compliance with preventive and hygiene measures.

In a recent study, it has been reported that Iranian 
medical students applied personal protection measures at a high rate during pandemic ${ }^{(6)}$. In our study, it was determined that the students applied personal protection measures at a high rate, except for the use of medical masks outside. At the time of this study, there was no clear suggestion about the use of masks outside. We think that the low rate of mask use is associated with this situation.

Increased alcohol and tobacco use after disasters has been shown in the majority of the publications investigating this relationship ${ }^{(6)}$. Contrary to previous data we found reduced amount of alcohol and tobacco use among medical school students. Findings from researches have shown that alcohol and smoking may worsen the course of SARS CoV-2 related diseases ${ }^{(10)}$. From this point of view, the decrease in smoking and alcohol use should be evaluated as a protective behavior which we found to be highly pursued in medical school students. Furthermore we can speculate that reduced smoking and alcohol consuption may be related to reduced socialization.

Although anxiety scores and ages of students didn't differ between three countries, tobacco and alcohol use were found to be at a highest level in students from TRNC and masks were most frequently used by students from Azerbaijan. This may be due to sociocultural differences between countries.

Center for Disease Control and Prevention (CDC) suggests avoiding overexposure to COVID-19 media broadcasts, eating a healthy, balanced diet, exercising regularly, sleeping regularly and adequately, avoiding alcohol and drugs, practicing one's favourite activities, connecting with others and maintaining healthy relationships in order to cope with stress and increase endurance against anxiety ${ }^{(13)}$. When the in-house activities performed by medical school students during isolation/quarantine period evaluated, it was determined that most frequently watching movies or TV series, spending time on social media and communicating with online applications, at least playing sports, and/or computer games, painting and other hobbies have been practiced.

The main method of relieving the anxiety felt by individuals in pandemics is to provide clear and reliable information. Frequent updates on data and developments will minimize panic and rumors ${ }^{(14)}$. In the online survey study that investigated the sources of university students' knowledge about the Ebola epidemic in the USA, it has been reported that official websites such as WHO and $\mathrm{NIH}$ were the least used sources, while conventional media and social media were most frequently referred sources (15). In the study evaluating the knowledge, behavior and risk perceptions of the medical students in Iran regarding the COVID-19 pandemic, it was reported that the students benefited from WHO, CDC and UptoDate more frequently than the local guidelines ${ }^{(6)}$. However, when evaluating these results, it should be remembered that the use of internet and social media in Iran is subject to restrictions. In our study, it was determined that the students benefited the least from the announcements of ministry of health and the most from their faculty members about the pandemic. They also benefited less from the WHO data compared to the social media sources. Our results point to the importance of social media among medical students in getting news and information about pandemic.

Outbreaks have been the subject of conspiracy theories throughout history ${ }^{(12)}$. Conspiracy theories have emerged about the Spanish flu, the Zika virus outbreak, the Swine flu outbreak, and even the Bubonic plague outbreak in Italy in 1576. HIV has been claimed to be a bioengineered weapon intended to eliminate homosexuality or Afro-Americans (16,17). In a study conducted in Nigeria, almost half of the participants stated that they believed that SARS CoV-2 was a biological weapon produced by China (18). In our study, one in three of the participants stated that they believed that SARS CoV-2 might be a biological weapon. Accurate information is essential in preventing conspiracy theories. While compliance with protection methods is strictly obeyed, strong belief in conspiracy theories suggests that the information these people have gotten is not convincing enough.

Increases in stigmatization can be expected in periods of pandemic, when public anxiety increases. Stigmatization involves negative, disparaging, hostile, 
devaluating, and discriminatory attitudes towards a person, group, and the geographic region affected by a particular disease, and issues related to the disease ${ }^{(20)}$. In the SARS epidemic, very similar to today's events, the British media linked the epidemic to the dirty market environment in China, their close living with animals, and to the improper hygienic and cultural behaviors of Chinese people (21). In Turkey, during the outbreak of the pandemic, stigmatization for the Asian people, then the elderly and ultimately the healthcare workers attracted attention in the media and social media. The way we express our thoughts about COVID-19 is critical in reducing stigmatization. In our study, unfortunately, it was determined that students did not take care not to use stigmatizing expressions in this way. Our results indicate that we should inform and educate students about the psychological effects and stigmatization of the pandemic.

In our study, the most important restrictive factor was failure to use a standard anxiety scale. However, the main purpose of this study is to determine the attitudes and behaviors of the students during the pandemic. Therefore, the students were asked to rate their anxiety levels. Reaching 1332 students in 3 different countries is one of the strongest aspects of our study.

\section{CONCLUSION}

The reduction in alcohol use and smoking rates is one of the most striking results of our study. Since the primary aim of our study was not to determine the rates of alcohol and tobacco use, screening tests for these subjects were not used. Longitudinal studies should be conducted in this regard.

In Turkey, medical faculties have started online education due to the current epidemic. Online tools are getting more and more effective in data collection and communication in the education of the students. For this reason, official institutions and universities should use social media more actively in informing the public. We also think it is important to educate future health professionals on social media literacy and sharing responsibilities. Thus, we can minimize the misinformation that spreads as fast as viruses, infects our minds, feeds our anxiety, conspiracy theories, stigmatization, erroneous beliefs and maladaptive behaviors.

\section{Acknowledgements:}

We would like to thank Ipek Baykan (Near East University, Faculty of Medicine) and Nərmin Quluzadə (Azerbaijan Medical University, Faculty of Treatment and Prevention) for their contributions in data acquisition.

Ethics Committee Approval: The ethics committee approval for the study was obtained from the NonInterventional Clinical Research Ethics Committee of Izmir Democracy University (dated March 20 2020 and numbered 2020/08-4). Approval of the Ministry of Health was obtained on May $5^{\text {th }} 2020$.

Conflict of Interest: None.

Funding: None.

Informed Consent: Informed consent was obtained from all participants.

\section{REFERENCES}

1. Guan WJ, Ni ZY, Hu Y, Liang WH, Ou CQ, He JX, et al; China Medical Treatment Expert Group for Covid-19. Clinical Characteristics of Coronavirus Disease 2019 in China. N Engl J Med. 2020 Apr 30;382(18):1708-20. https://doi.org/10.1101/2020.02.06.20020974

2. Miller DG, Pierson L\&Doernberg S. The Role of Medical Students During the COVID-19 Pandemic. Annals of Internal Medicine. 2020. https://doi.org/10.7326/L20-1195

3. Baker DM, Bhatia S, Brown S, Cambridge W, Kamarajah SK, McLean KA, et al. Medical student involvement in the COVID-19 response. The Lancet., 2020. https://doi.org/10.1016/S0140-6736(20)30795-9

4. Wang C, Pan R, Wan X, Tan Y, Xu L, Ho CS, Ho RC. Immediate Psychological Responses and Associated Factors during the Initial Stage of the 2019 Coronavirus Disease (COVID-19) Epidemic among the General Population in China. Int J Environ Res Public Health. 2020 Mar 6;17(5). https://doi.org/10.3390/ijerph17051729

5. Cao W, Fang Z, Hou G, Han M, Xu X, Dong J et al. The psychological impact of the COVID-19 epidemic on college students in China. Psychiatry Research, 112934, 2020. https://doi.org/10.1016/j.psychres.2020.112934

6. Taghrir MH, Borazjani R, Shiraly R. COVID-19 and Iranian Medical Students; A Survey on Their Related-Knowledge, Preventive Behaviors and Risk Perception. Arch Iran Med. 2020 Apr 1;23(4):249-54. https://doi.org/10.34172/aim.2020.06 
7. Barello S, Palamenghi L, Graffigna G. Burnout and somatic symptoms among frontline healthcare professionals at the peak of the Italian COVID-19 pandemic. Psychiatry Research. 2020;113129.

https://doi.org/10.1016/j.psychres.2020.113129

8. Rossi R, Socci V, Pacitti F, Di Lorenzo G, Di Marco A, Siracusano $A$, et al. Mental Health Outcomes Among Frontline and Second-Line Health Care Workers During the Coronavirus Disease 2019 (COVID-19) Pandemic in Italy. JAMA Network Open. 2020;3(5):e2010185-e2010185. https://doi.org/10.1001/jamanetworkopen.2020.10185

9. Lai J, Ma S, Wang Y, Cai Z, Hu J, Wei N, et al. Factors associated with mental health outcomes among health care workers exposed to coronavirus disease 2019. JAMA network open. 2020;3(3):e203976-e203976. https://doi.org/10.1001/jamanetworkopen.2020.3976

10. Nordløkken A, Pape $H$, Heir T. Alcohol consumption in the aftermath of a natural disaster: a longitudinal study. Public Health, 2016;132:33-9. https://doi.org/10.1016/j.puhe.2015.11.007

11. Marsden J, Darke S, Hall W, Hickman M, Holmes J, Humphreys, $\mathrm{K}$, et al. Mitigating and learning from the impact of COVID-19 infection on addictive disorders. Addiction, 2020. https://doi.org/10.1111/add.15080

12. Taylor S. The psychology of pandemics: Preparing for the next global outbreak of infectious disease. Cambridge Scholars Publishing, 2019.

13. http://www.cdc.gov/coronavirus/2019-ncov/about/coping. html

14. Duan C, Linder H, Huremović, D. Societal, Public, and [Emotional] Epidemiological Aspects of a Pandemic. In
Psychiatry of Pandemics (pp. 45-53). Springer, Cham, 2019. https://doi.org/10.1007/978-3-030-15346-5_4

15. Koralek T, Runnerstrom MG, Brown BJ, Uchegbu C, Basta TB. Lessons from Ebola: Sources of Outbreak Information the Associated Impact on UC Irvine and Ohio University College Students. PLoS Curr. 2016 Aug 25;8.

https://doi.org/10.1371/currents.outbreaks. f1f5c05c37a5ff8954f38646cfffc6a2

16. Helier J. Rumors and realities: Making sense of HIV/AIDS conspiracy narratives and contemporary legends. American Journal of Public Health, 2015;105:e43-e50. https://doi.org/10.2105/AJPH.2014.302284

17. Parsons S, Simmons W, Shinhoster F, Kilburn J. (1999). A test of the grapevine: An empirical examination of conspiracy theories among African Americans. Sociological Spectrum, 1999;19:201-22. https://doi.org/10.1080/027321799280235

18. PO, O., SO, K., JC, G., AL, D., \& IFA, O. (2020). A Preliminary Assessment of Novel Coronavirus (COVID-19) Knowledge and Perceptions in Nigeria.

19. Oliver JE, Wood T. Medical conspiracy theories and health behaviors in the United States. JAMA Internal Medicine, 2014;174:817-8. https://doi.org/10.1001/jamainternmed.2014.190

20. "Reducing Stigma", Centers for Disease Control and PreventionCOVID19. https://www.cdc.gov/coronavirus/2019-ncov/ symptoms-testing/reducing-stigma.html

21. Washer P. Representations of SARS in the British newspapers. Social Science and Medicine, 2004;59:2561-71. https://doi.org/10.1016/j.socscimed.2004.03.038 